\title{
Discrimination by parity is a prerequisite for assessing induction of labour outcome - cross-sectional study
}

\author{
Branko Denona ${ }^{1,2^{*}}$ Dichael Foley ${ }^{1}$, Rhona Mahony ${ }^{1}$ and Michael Robson ${ }^{1}$
}

\begin{abstract}
Background: To demonstrate that studies on induction of labour should be analyzed by parity as there is a significant difference in the labour outcome among induced nulliparous and multiparous women.

Methods: Obstetric outcome, specifically caesarean section rates, among induced term nulliparous and multiparous women without a previous caesarean section were analyzed in this cross-sectional study using the Robson 10 group classification for the year 2016.

Results: In the total number of 8851 women delivered in 2016, the caesarean section rates among nulliparous women in spontaneous and induced labour, Robson groups 1 and 2A, were 7.84\% (151/1925) and 32.63\% (437/ 1339) respectively and among multiparous (excluding those women with a previous caesarean section), Robson group 3 and 4A were 1\%(24/2389) and 4.37\% (44/1005), respectively. Pre labour caesarean rates for nulliparous and multiparous women, Robson groups 2B and 4B (Robson M, Fetal Matern Med Rev, 12; 23-39, 2001) were 3.91\% (133/3397) and 2.86\% (100/3494), of the respective single cephalic cohort at term.
\end{abstract}

Conclusion: The data suggests that studies on induction of labour should be analyzed by parity as there is a significant difference between nulliparous and multiparous women.

Keywords: Nulliparous women, Multiparous women, Induction of labour

\section{Background}

The overall induction of labour rate in Ireland is $25 \%$ [1]. The induction rate among single cephalic nulliparous women, $\geq 37$ weeks of gestation cohort group has increased in our hospital from $17.5 \%$ when the Robson classification [2] was introduced in 1994 to $39.41 \%$ in 2016 (Table 1). This increase in the induction rate is due to a variety of reasons including, 'prolonged pregnancy', gestational diabetes, cholestasis in pregnancy, patient's request; indications which are usually recurrent and will, most likely, present a problem in subsequent

\footnotetext{
* Correspondence: branko.denona@gmail.com

${ }^{1}$ National Maternity Hospital, Dublin, Ireland

${ }^{2}$ St. Luke's General Hospital, Kilkenny, Ireland
}

pregnancies for women who have been delivered by caesarean section for failed induction in their first pregnancy.

A PubMed search (years 2010-2016) for publications on induction of labour was performed to determine how many abstracts mentioned parity. A search produced 404 abstracts of which only 77(19.05\%) specifically stated that the study was confined to nulliparous or multiparous women. Of the remaining, 136(33.66\%) mentioned parity as a variable in the analysis of results and 191 (47.27\%) did not mention parity at all.

From clinical perspective, induction of labour in nulliparous women carries higher risk of caesarean section due to failed process of induction compared to

C C The Author(s). 2020 Open Access This article is licensed under a Creative Commons Attribution 4.0 International License, which permits use, sharing, adaptation, distribution and reproduction in any medium or format, as long as you give appropriate credit to the original author(s) and the source, provide a link to the Creative Commons licence, and indicate if changes were made. The images or other third party material in this article are included in the article's Creative Commons licence, unless indicated otherwise in a credit line to the material. If material is not included in the article's Creative Commons licence and your intended use is not permitted by statutory regulation or exceeds the permitted use, you will need to obtain permission directly from the copyright holder. To view a copy of this licence, visit http://creativecommons.org/licenses/by/4.0/ The Creative Commons Public Domain Dedication waiver (http://creativecommons.org/publicdomain/zero/1.0/) applies to the data made available in this article, unless otherwise stated in a credit line to the data. 
Table 1 Robson 10 group classification and the results for NMH 2016

\begin{tabular}{|c|c|c|c|c|c|}
\hline Group & Description & $\begin{array}{l}\text { Total numbers of } \\
\text { caesarean sections } \\
(2303 / 8851)\end{array}$ & $\begin{array}{l}\text { Contribution of the } \\
\text { group in overall } \\
\text { hospital population }\end{array}$ & $\begin{array}{l}\text { Caesarean section } \\
\text { rate within each } \\
\text { group }\end{array}$ & $\begin{array}{l}\text { Contribution of } \\
\text { each group to } \\
\text { overall CS (26\%) }\end{array}$ \\
\hline 1 & $\begin{array}{l}\text { Nulliparous, single cephalic, }>=37 \text { weeks, in } \\
\text { spontaneous labour }\end{array}$ & $151 / 1925$ & $21.74 \%$ & $7.84 \%$ & $1.70 \%$ \\
\hline 2 & $\begin{array}{l}\text { Nulliparous, single cephalic, > = } 37 \text { weeks, } \\
\text { induced and CS before labour }\end{array}$ & $570 / 1472$ & $16.63 \%$ & $38.72 \%$ & $6.43 \%$ \\
\hline $2 \mathrm{~A}$ & $\begin{array}{l}\text { Nulliparous, single cephalic, > = } 37 \text { weeks, } \\
\text { induced }\end{array}$ & $437 / 1339$ & $15.12 \%$ & $32.63 \%$ & $4.93 \%$ \\
\hline $2 B$ & $\begin{array}{l}\text { Nulliparous, single cephalic, > = } 37 \text { weeks, } \\
\text { CS before labour }\end{array}$ & 133 & $1.50 \%$ & $100 \%$ & $1.50 \%$ \\
\hline 3 & $\begin{array}{l}\text { Multiparous (excluding prev. CS), single } \\
\text { cephalic, }>=37 \text { weeks, in spontaneous labour }\end{array}$ & $24 / 2389$ & $26.99 \%$ & $1 \%$ & $0.27 \%$ \\
\hline 4 & $\begin{array}{l}\text { Multiparous (excluding prev. CS), single } \\
\text { cephalic, }>=37 \text { weeks, induced and CS } \\
\text { before labour }\end{array}$ & $144 / 1105$ & $12.48 \%$ & $13.03 \%$ & $1.62 \%$ \\
\hline $4 \mathrm{~A}$ & $\begin{array}{l}\text { Multiparous (excluding prev. CS), single } \\
\text { cephalic, }>=37 \text { weeks, induced }\end{array}$ & $44 / 1005$ & $11.35 \%$ & $4.37 \%$ & $0.49 \%$ \\
\hline $4 \mathrm{~B}$ & $\begin{array}{l}\text { Multiparous (excluding prev. CS), single } \\
\text { cephalic, }>=37 \text { weeks, CS before labour }\end{array}$ & 100 & $1.12 \%$ & $100 \%$ & $1.12 \%$ \\
\hline 5 & Previous CS, single cephalic, $>=37$ weeks & $821 / 1069$ & $12.07 \%$ & $76.80 \%$ & $9.27 \%$ \\
\hline 6 & All nulliparous breeches & $162 / 171$ & $1.93 \%$ & $94.73 \%$ & $1.83 \%$ \\
\hline 7 & All multiparous breeches (including prev. CS) & $115 / 124$ & $1.40 \%$ & $92.74 \%$ & $1.29 \%$ \\
\hline 8 & All multiple pregnancies (including prev. CS) & $119 / 187$ & $2.11 \%$ & $63.63 \%$ & $1.34 \%$ \\
\hline 9 & All abnormal lies (including prev. CS) & 30 & $0.33 \%$ & $100 \%$ & $0.33 \%$ \\
\hline 10 & $\begin{array}{l}\text { All single cephalic, }<=36 \text { weeks } \\
\text { (including prev. CS) }\end{array}$ & $167 / 379$ & $4.28 \%$ & $44.06 \%$ & $1.88 \%$ \\
\hline
\end{tabular}

multiparous women and we investigated our data collected over a period of 1 year to see our results.

\section{Methods}

This was a cross-sectional study of data collected at the time of delivery on a computer database at the National Maternity Hospital, Dublin in year 2016. Caesarean section rates for term single cephalic nulliparous and multiparous women without previous uterine scar, were taken from data published in the annual hospital report. The indication for induction were classified under 6 headings: preeclampsia (hypertension and proteinuria)/ hypertension, postdates $>=42$ weeks, SROM, maternal reasons/pains, fetal reasons (IUGR, reduced liquor, GDM, obstetric cholestasis and others.) and nonmedical reasons (maternal request for postdates in prolonged pregnancy but not $>=42$ weeks) (Table 4 ).

The classification of caesarean section, performed during induction process or after labour was diagnosed, was classified as fetal reasons (without the use of oxytocin) and dystocia (which was further sub classified) [3, 4] (Table 5).

Following admission for induction of labour a CTG was performed and the cervix was assessed by an experienced obstetrician. When the cervix was thought to be favorable artificial rupture of the membranes was performed (ARM) and an oxytocin infusion was commenced the following day if labour had not commenced.

When the cervix was deemed to be unfavorable, a prostaglandin PGE2 intravaginal gel was administrated and repeated if necessary, in $6 \mathrm{~h}$ provided the repeat CTG were normal. Number of women were treated with Propess instead of PGE2 gel by the same principle. If labour had not commenced by the following day, the induction process was repeated, ARM or prostaglandin gel. When there was no change in cervical status after 2 days of induction process, a caesarean section was performed but was included in Robson group 2A or 4A. Bishop score is not regularly used in our hospital, so the changes in cervix are noted in length and dilatation measured in centimeters and progress evaluated on this observations.

\section{Results}

The induction rate among single cephalic nulliparous women at term ( $\geq 37$ weeks of gestation) increased from $17.5 \%$ in 1994 to $39.41 \%$ in 2016 and caesarean section rate increased from $21.5 \%$ (97/451) to $32.63 \%$ (437/1339) respectively. The induction rate among term multiparous women without previous caesarean section (group 4A) increased from $17.02 \%$ in $1994(626 / 3677)$ to $28.76 \%$ (1005/ 
Table 2 Patient demographics, method of induction, maternal and fetal outcome (NMH 2016)

\begin{tabular}{|c|c|c|c|c|}
\hline & Group 2A & Group 4A & $95 \% \mathrm{Cl}$ & $p$-value \\
\hline Age $>=35$ years & 439/1339 (32.78\%) & $531 / 1005(52.83 \%)$ & 15.9 to 23.9 & $P<0.0001$ \\
\hline $\mathrm{BMI}=>30$ & 166/1339 (12.39\%) & 145/1005 (14.42\%) & -0.7 to 4.8 & $P=0.1577$ \\
\hline Prostaglandin gel/Propess & $666 / 1339(49.73 \%)$ & $348 / 1005$ (34.62\%) & 11 to 19 & $P<0.0001$ \\
\hline Oxytocin & $961 / 1339$ (71.76\%) & $323 / 1005$ (32.13\%) & 35.8 to 43.3 & $P<0.0001$ \\
\hline Artificial rupture of membranes & $882 / 1339(65.87 \%)$ & $851 / 1005$ (84.67\%) & 15.3 to 22.1 & $P<0.0001$ \\
\hline Fetal blood sampling & $380 / 1339$ (28.37\%) & 68/1005 (6.76\%) & 18.6 to 24.4 & $P<0.0001$ \\
\hline Vaginal operative delivery & $392 / 1339(29.27 \%)$ & $57 / 1005(5.67 \%)$ & 20.7 to 26.3 & $P<0.0001$ \\
\hline Full dilatation caesarean section & $34 / 1339(2.53 \%)$ & 2/1005 (0.19\%) & 1.4 to 3.2 & $P<0.0001$ \\
\hline $\mathrm{PPH}=>1000 \mathrm{ml}$ & $63 / 1339(4.70 \%)$ & $27 / 1005$ (2.68\%) & 0.4 to 3.5 & $P=0.0127$ \\
\hline HIE & $5 / 1339(0.37 \%)$ & 0/1005 (0\%) & -0.1 to 0.9 & $P=0.0448$ \\
\hline Blood transfusion & 45/1339 (3.36\%) & 9/1005 (0.89\%) & 1.3 to 3.6 & $P=0.0001$ \\
\hline OASIS & 29/1339 (2.16\%) & $12 / 1005(1.19 \%)$ & -0.1 to 2.1 & $P=0.0694$ \\
\hline Apgar $<7$ at $5 \mathrm{~min}$. & 20/1339 (1.49\%) & 8/1005 (0.79\%) & -0.2 to 1.5 & $P=0.1235$ \\
\hline Cord $\mathrm{pH}<7.0$ & $5 / 1339(0.37 \%)$ & 2/1005 (0.19\%) & -0.3 to 0.7 & $P=0.3920$ \\
\hline Admission to Neonatal unit & 405/1339 (30.24\%) & 145/1005 (14.42\%) & 12.4 to 19 & $P<0.0001$ \\
\hline Babies $>=4 \mathrm{~kg}$ & 242/1339 (18.07\%) & 264/1005 (26.26\%) & 4.8 to 11.6 & $P<0.0001$ \\
\hline Episiotomy & $570 / 1339(42.56 \%)$ & $85 / 1005$ (8.45\%) & 30.8 to 37.1 & $P<0.0001$ \\
\hline Epidural & 1023/1339 (76.40\%) & $517 / 1005$ (51.44\%) & 21.1 to 28.7 & $P<0.0001$ \\
\hline Electronic monitoring & 1238/1339 (92.45\%) & 913/1005 (90.84\%) & -0.5 to 4 & $P=0.1384$ \\
\hline Length of labour $>12 \mathrm{~h}$ & 103/1339 (7.69\%) & 9/1005 (0.89\%) & 5.2 to 8.4 & $P<0.0001$ \\
\hline
\end{tabular}

3494) in 2016 and the respective caesarean section rates were $5.11 \%(32 / 626)$ in 1994 and $4.37 \%$ in 2016 (44/1005).

There were 8851 women delivered in 2016 of whom 3397 were in Robson group 1 and 2. Among these 56.66\% (1925/3397) went into spontaneous labour, 39.41\% (1339/3397) were induced and 3.91\% (133/3397) had pre labour caesarean section. The corresponding number for multiparous women in Robson group 3 and 4 were $68.37 \%(2389 / 3494), 28.76 \%$ (1005/3494) and $2.86 \%(100 / 3494)$. Excluded from analysis from multiparous women group were 1069 women with at least 1 previous caesarean section and a single cephalic pregnancy (Robson group 5).

Patient demographics, method of induction, obstetric and neonatal outcome are shown in Table 2. Of note, group 4A were significantly older and had significantly larger babies. However, the percentage of obese women $(\mathrm{BMI}=>30)$ was similar. More nulliparous women required prostaglandins combined with oxytocin infusion for induction (Table 2).

The caesarean rates among nulliparous women in spontaneous and induced labour, groups 1 and 2A, were $7.84 \%(151 / 1925)$ and $32.63 \%(437 / 1339)$ and among multiparous, group 3 and 4A were 1\% (24/2389) and $4.37 \%$ (44/1005), respectively (Table 3 ).
Overall, the caesarean section rate by indication was lowest in both groups when the indication for induction was for fetal reasons or maternal pains. Among nulliparous women, the highest caesarean section rate by indication were for postdates pregnancies $(=>42$ weeks) and for nonmedical reasons and late pregnancies $<42$ weeks (Table 4).

The indications for caesarean sections are shown in Table 5 and as expected, the main difference between group 2A and 4A was the number indicated for dystocia and suspected fetal distress (Table 5).

\section{Discussion}

As the number of inductions are seemingly increasing there is a realization that the most significant groups to study are groups $2 \mathrm{~A}$ and $4 \mathrm{~A}$ from the Robson classification; in particular, group $2 \mathrm{~A}$.

Table 3 Caesarean section rates among nulliparous and multiparous women in spontaneous and induced labour (NMH 2016)

\begin{tabular}{lll}
\hline & Spontaneous labor & Induced labour \\
\hline Nulliparous women & $7.84 \%(151 / 1925)$ & $32.63 \%(437 / 1339)$ \\
Multiparous women & $1 \%(24 / 2389)$ & $4.37 \%(44 / 1005)$ \\
\hline
\end{tabular}


Table 4 Indications for induction among group 2A and 4A and the associated caesarean section rates (NMH 2016)

\begin{tabular}{lllll}
\hline & Group 2A $(\boldsymbol{n}=\mathbf{1 3 3 9})$ & CS rate for group 2A & Group 4A $(\boldsymbol{n}=\mathbf{1 0 0 5})$ & CS rate for group 4A \\
\hline Fetal reasons & $32.48 \%(435)$ & $26.43 \%(115 / 435)$ & $27.56 \%(277)$ & $4.33 \%(12 / 277)$ \\
SROM & $24.42 \%(327)$ & $33.02 \%(108 / 327)$ & $14.72 \%(148)$ & $6.08 \%(9 / 148)$ \\
Postdates (> = 42 weeks) & $14.86 \%(199)$ & $44.22 \%(88 / 199)$ & $12.83 \%(129)$ & $3.87 \%(5 / 129)$ \\
PET/hypertension & $11.87 \%(159)$ & $29.55 \%(47 / 159)$ & $5.87 \%(59)$ & $6.77 \%(4 / 59)$ \\
Maternal reasons (including pains) & $9.03 \%(121)$ & $26.44 \%(32 / 121)$ & $19.20 \%(193)$ & $3.10 \%(6 / 193)$ \\
Nonmedical reasons/dates (<42 weeks) & $7.31 \%(98)$ & $48.0 \%(47 / 98)$ & $19.80 \%(199)$ & $4.02 \%(8 / 199)$ \\
Total & $39.4 \%(1339)$ & $32.63 \%(437 / 1339)$ & $28.8 \%(1005)$ & $4.37 \%(44 / 1005)$ \\
\hline
\end{tabular}

From our data, nulliparous women are three to four times more likely to be delivered by caesarean section when labour is induced. Despite every effort over the years to address this important clinical problem including ARM, oxytocin infusion and prostaglandin in a variety of combinations, it seems that induction of labour in nulliparous women remains a challenge. In delivery units that report lower caesarean section rates in nulliparous women who are being induced it is often associated with a much longer labour process something which is certainly not viewed positively by all women and may have higher postpartum hemorrhage rates. In addition, it is not easy to audit the results in that induction of labour needs to be compared with expectant management and not directly with spontaneous labour [4].

On the other hand, multiparous women who have previously delivered vaginally and without a cesarean section are the lowest risk of our obstetric population with a low cesarean rate birth in spontaneous and induced labour, looking at our results. Achieving vaginal delivery in nulliparous women therefore seems important. The cesarean rate for nulliparous by indication for induction is important and the rate seems highest in those induced in late pregnancy either for the strict definition of $>=42$ weeks or those induced for nonmedical reason or dates $<42$ weeks.

We fully appreciate limitations of this study which include possible wrong allocation of certain number

Table 5 Indication for cesarean delivery among Robson group $2 \mathrm{~A}$ and $4 \mathrm{~A}$

\begin{tabular}{lll}
\hline & Group 2A $(\boldsymbol{n}=\mathbf{1 3 3 9})$ & Group 4A $(\boldsymbol{n}=\mathbf{1 0 0 5})$ \\
\hline Fetal reasons & $7.5 \%(100)$ & $1.0 \%(10)$ \\
Dystocia/IUA/ITT/FI & $9 \%(121)$ & $0.8 \%(8)$ \\
Dystocia/IUA/ITT/OC & $5 \%(68)$ & $0.7 \%(7)$ \\
Dystocia/IUA/PR & $8.1 \%(108)$ & $1.4 \%(14)$ \\
Dystocia (no oxytocin) & $1.1 \%(15)$ & $0.1 \%(1)$ \\
Dystocia/EUA/CPD/POP & $1.9 \%(25)$ & $0.4 \%(4)$ \\
Total & $32.6 \%(437)$ & $4.4 \%(44)$ \\
\hline
\end{tabular}

of patients in observed groups which would be nonsignificant for the overall result, difference between examiners of patients and slight adjustments in induction of labour process.

\section{Conclusions}

As we search for new methods for induction of labour we believe that the data presented here provides evidence that trials on labor induction should be more focused on nulliparous women. We have not attempted to address the separate and contentious problem of labour induction in women with a previous cesarean section; avoiding the first cesarean section seems to be the only solution, either by trying to avoid induction or prelabour caesarean section when possible; or by introducing new techniques to increase the success of induction of labour.

\section{Abbreviations}

AROM: Artificial rupture of membranes; SROM: Spontaneous rupture of membranes; IUGR: Intrauterine growth restriction; GDM: Gestational diabetes mellitus; IUA: Inefficient uterine activity; EUA: Efficient uterine activity; ITT: Inability to treat; FI: Fetal intolerance; OC: Over contracting; PR: Poor response; CPD: Cephalopelvic disproportion; POP: Persistent occiput posterior

\section{Acknowledgments}

Authors would like to thank all the staff in the National Maternity Hospital who have helped collecting the data especially Tina Murphy who has sadly died.

\section{Authors' contributions}

Dr. BD and Prof. MF designed the study, performed analysis and interpretation of the data. Dr. MR performed the review of the study and the interpretation of the data and made significant changes to it. Dr. RM made a significant contribution in design and concept of the study. All authors have read and approved the manuscript.

\section{Funding}

No funding declared.

Availability of data and materials

All the data used in this study is published in hospital annual report and is available from the hospital on reasonable request.

Ethics approval and consent to participate

Ethics committee approval has been waived as the data used in this study is published in the hospital annual report and therefore, it is accessible to the public. 


\section{Consent for publication}

Not applicable.

\section{Competing interests}

The authors declare that they have no competing interests.

Received: 25 October 2019 Accepted: 13 October 2020

Published online: 23 November 2020

\section{References}

1. Sinnotts SJ, Layte R, Brick A, Turner MJ. Variation in induction of labour rates across Irish hospitals; a cross-sectional study. Eur J Pub Health. 2016 Oct; 26(5):753-60.

2. Robson M. Classification of caesarean sections. Fetal Maternal Med Rev. 2001;12(1):23-39.

3. Robson M, Murphy M, Byrne F. Quality assurance: The 10-Group Classification System (Robson classification), induction of labor, and cesarean delivery. Int J Gynecol Obstet. 2015;131:S23-7.

4. Little SE, Caughey AB. Induction of labor and cesarean: what is the true relationship? Clin Obstet Gynecol. 2015 Jun;58(2):269-81.

\section{Publisher's Note}

Springer Nature remains neutral with regard to jurisdictional claims in published maps and institutional affiliations.

- fast, convenient online submission

- thorough peer review by experienced researchers in your field

- rapid publication on acceptance

- support for research data, including large and complex data types

- gold Open Access which fosters wider collaboration and increased citations

- maximum visibility for your research: over $100 \mathrm{M}$ website views per year

At $\mathrm{BMC}$, research is always in progress. 